\title{
Oral cancer of Sigmund Freud
}

\author{
Afshin Teymoortash $^{1}$ (1) Alfio Ferlito ${ }^{2}$
}

Received: 29 January 2019 / Accepted: 2 February 2019 / Published online: 8 February 2019

c) Springer-Verlag GmbH Germany, part of Springer Nature 2019

We read with great interest the theory of Trimarchi et al. [1] about the possible cocain-induced disease of Sigmund Freud. The authors disregard the fact that the oral disease of Sigmund Freud was a repeatedly histologically proven squamous cell carcinoma of the oral cavity in a heavy smoker patient.

The protracted course and long survival from his incompletely resected oral cancer correspond to a highly differentiated variant of squamous cell carcinoma with slow-growing invasive pattern of a verrucous carcinoma we published in this journal before [2].

\section{Compliance with ethical standards}

Conflict of interest The authors declare that they have no conflict of interest.
Human and animal rights This article does not contain any studies with human participants or animals performed by any of the authors.

Informed consent Not needed.

\section{References}

1. Trimarchi M, Bertazzoni G, Bussi M (2019) The disease of Sigmund Freud: oral cancer or cocaine-induced lesion? Eur Arch Otorhinolaryngol 276:263-265

2. Teymoortash A, Silver CE, Rinaldo A, Cardesa A, Folz BJ, Ferlito A (2014) Verrucous carcinoma: a retrospective diagnosis in three historic patients. Eur Arch Otorhinolaryngol 2014 271:631-633

Publisher's Note Springer Nature remains neutral with regard to jurisdictional claims in published maps and institutional affiliations.
Afshin Teymoortash

prof-at@hno-zentrum-mittelhessen.de

1 Center for Otolaryngology, Head and Neck Surgery of Mittelhessen, Krummbogen 15, 35039 Marburg, Germany

2 International Head and Neck Scientific Group, Padua, Italy 